doi: 10.5862/MCE.68.2

\title{
Geothermal heat pump in the passive house concept
}

\section{Геотермальный тепловой насос в концепции пассивного дома}

\author{
V.A. Kostenko, \\ N.M. Gafiyatullina, \\ A.A. Semchuk, \\ M.I. Kukolev, \\ Peter the Great St. Petersburg Polytechnic \\ University, St. Petersburg, Russia
}

\author{
Студент В.А. Костенко, \\ студент Н.М. Гафиятуллина, \\ студент А.А. Семчук, \\ д-р. техн.наук, профессор М.И. Куколев, \\ Санкт-Петербургский политехнический \\ университет Петра Великого, Санкт- \\ Петербург, Россия
}

Key words: energy efficiency; buildings; construction; energy saving; passive house; alternative energy source; geothermal energy; heat pumps; feasibility study

\begin{abstract}
Ключевые слова: энергоэффрективность; здания; сооружения; энергосбережение; пассивный дом; альтернативный источник энергии; геотермальная энергия; тепловой насос; технико-экономическое обоснование
\end{abstract}

Abstract. An actual problem is reducing the cost of engineering systems maintenance of buildings and constructions. These costs include transportation of energy resources from source to consumer, complexity of the heating systems, caused by a large amount of equipment, and as a consequence, the presence of excessive heat losses. One solution is construction of buildings that meet modern energy efficiency requirements.

A set of parameters that contribute to the implementation of the "Passive House" concept was considered, including the use of geothermal heat pumps for the heating system as an alternative production of thermal energy. The main characteristics of the heat pump were established. It was revealed that the cost of heating and air conditioning will not exceed the maximum. The economic efficiency of the chosen technical solution was considered. This research has the prospect of further development.

Аннотация. Актуальной проблемой является снижение затрат на обслуживание инженерных систем зданий и сооружений. К таким затратам относят транспортировку энергоресурсов от источника к потребителю, сложность систем теплоснабжения, обусловленная большим количеством оборудования, и как следствие, наличие излишних тепловых потерь. Одним из решений является строительство зданий, соответствующих современным требованиям энергоэффективности.

Был рассмотрен комплекс параметров, которые способствуют реализации концепции «Пассивный дом». В том числе применение геотермальных тепловых насосов в качестве альтернативного производства тепловой энергии для системы теплоснабжения. Установлены основные характеристики для теплового насоса. Выявлено, что затраты на отопление и кондиционирование не будут превышать установленный максимум. Рассмотрена экономическая эффективность выбранного технического решения. Данное исследование имеет перспективу дальнейшего развития.

\section{Introduction}

Implementation of energy efficiency measures can significantly reduce the amount of energy consumption and the cost of payment for utility services. Energy saving effect is achieved through the sum of architectural, construction and engineering solutions aimed at energy savings [1-6].

At the stage of architectural, constructive and engineering design energy efficiency is achieved by: 
- reduction of the outer shell specific area per unit volume is achieved by the most compact space layout;

- targeted selection of the object shape and orientation in view of the energy field properties of renewable sources;

- increase of external cladding thermal properties through the use of efficient thermal insulation materials;

- capacity control of combined extract-and-input systems in accordance with the required air exchange in the attended rooms and as a consequence avoiding of heat overspending in ventilation systems heaters;

- installation of the system of automatic electronic control of the internal building temperature;

- the use of alternative sources of energy for building heat supply.

An indicator of energy efficiency of the object is the number of heat energy consumption per square meter $\left(\mathrm{kW} \cdot \mathrm{h} / \mathrm{m}^{2}\right)$ during the year or the heating season $[3,11,12]$. On average, it amounts to $70-$ $140 \mathrm{~kW} \cdot \mathrm{h} / \mathrm{m}^{2}$ for buildings constructed after 2015 [7]. Passive House is a building, where this indicator does not exceed $15 \mathrm{~kW} \cdot \mathrm{h} / \mathrm{m}^{2}$ [8, 9]. This criterion is achieved through intelligent design and implementation of the 5 Passive House principles: proper shape of the building, thermal bridge free design, good insulation of the building outer shell, combined extract-and-input ventilation system with heat recovery, alternative energy sources. Buildings complying with the Passive House standard [8] are rapidly spreading across Germany, Austria and Switzerland. In Germany, the current growth rate of buildings complying with the Passive House standard amounts to $100 \%$, and in January 2004, more than 4000 dwelling units (equivalent to about $100 \mathrm{~m}^{2}$ each) had been built.

To significantly reduce the ever-increasing demand for energy, it is necessary to use different approaches that limit its consumption. It is necessary to reduce heat losses, as well as to organize a more economical method of producing energy, for example, from renewable energy sources. Only a combination of several solutions can give a rational economy.

The aim of this study is to determine the possibility of applying heat pumps in the design of Passive House in the given climatic and geographical conditions.

To achieve this goal, it is necessary to solve the following objectives:

1. Determine the optimal location in the space of a given geographical position.

2. Develop architectural planning and design solutions.

3. Propose technical solutions to reduce energy consumption.

4. Perform a feasibility study of the selected technical solutions.

\section{Methods}

The object of the research is a two-story 7-apartment townhouse for year-round use. The projected building is located in the Vyborg district of the Leningrad region, on the shore of Glubokoye Lake. The terrain of the area is particularly distinguished by the presence of hilly and granite rocks in the ground. The advantage of the chosen type of structure is a decrease in the number of external walls and vertical distribution of rooms, thereby area of the roof is reduced.

Calculate the compactness coefficient:

$$
\mathrm{K}_{\mathrm{K}}=\frac{\mathrm{A}_{\mathrm{H}}^{\mathrm{sum}}}{\mathrm{V}_{\mathrm{H}}},
$$

where $\mathrm{A}_{\mathrm{H}}^{\text {sum }}$ - sum of the building envelope areas, $\mathrm{m}^{2}$;

$\mathrm{V}_{\mathrm{H}}$ - heated volume of the building, $\mathrm{m}^{3}$.

In this case, the compactness coefficient is 0.61 , which corresponds to the norm for the two-storey slab blocks [10].

Orientation of the glazed facade is directed to the southwest party that will favorably influence natural lighting and inflow of heat from solar radiation [3, 4].

As in most European countries with high requirements to the level of thermal protection of building envelopes, it is planned to apply frame technology in the projected building. To meet requirements imposed on Passive House it is necessary to choose the optimum thickness of insulation. Through the

Костенко В.А., Гафиятуллина Н.М., Семчук А.А., Куколев М.И. Геотермальный тепловой насос в концепции пассивного дома // Инженерно-строительный журнал. 2016. № 8(68). С. 18-25. 
use of the most effective insulation thickness of the walls of frame buildings is the lowest in comparison with similar (wood and stone) [11]. In this case to use the product from innovative heat-insulating material is offered - cellulose wool, the thermal conductivity is equal to $0.04 \mathrm{~W} / \mathrm{m} \cdot \mathrm{K}$.

Installation of an Air Handling Unit with recuperation will help to achieve comfortable microclimate. This system purifies and humidifies air, which is essential in the city conditions [8, 18].

For Heat Losses calculation through enclosure it's very convenient to use the value inverse to the reduced total thermal resistance, which in International Standards is called heat-transfer coefficient or Uvalue.

It is convenience is encompassed in its dimension: $\mathrm{W} / \mathrm{m}^{2 .{ }^{\circ} \mathrm{C}}$.

The value given shows which amount of heat energy goes through enclosure with the area $1 \mathrm{~m}^{2}$ under the internal and external temperature difference of $1 \stackrel{\circ}{\circ} \mathrm{C}$ from both the sides of enclosure. For heat calculation amount $(\mathrm{kW} \cdot \mathrm{h})$ going through $1 \mathrm{~m}^{2}$ of an external wall, $\mathrm{U}$-value must be multiplied by the amount of heating period hours and middle temperature difference of a heating period. This data is defined for every climatic region in standard [12]. Finally, we get summary heat energy losses through $1 \mathrm{~m}^{2}$ of exterior wall with the value of heat-transfer coefficient equal to $U=0.4 \mathrm{~W} / \mathrm{m}^{2 .}{ }^{\circ} \mathrm{C}$ :

$$
\mathrm{Q}=\frac{\mathrm{U} \cdot\left(\mathrm{t}_{\mathrm{in}}-\mathrm{t}_{\mathrm{h}}\right) \cdot \mathrm{z}_{\mathrm{h}} \cdot 24}{1000},
$$

where $t_{\text {in }}$ - inner temperature of air in a room, taken according to standard [13] equal to $20^{\circ} \mathrm{C}$;

$t_{h}$ - middle temperature of outer air for a heating period, taken for climate conditions of the Leningrad Region according to standard [12] equal to minus $2.9^{\circ} \mathrm{C}$;

$\mathrm{Z}_{\mathrm{h}}$ - the amount of days in a heating period, taken for Civil Engineering, located on the territory of the Leningrad Region - 228 days;

24 - the number of hours in a day;

1000 - conversion coefficient of heat transfer capacity (from W into kW). $\mathrm{kW} \cdot \mathrm{h}$.

Thus, using the formula (2) we can calculate average heat losses for a heating period for $1 \mathrm{~m}^{2}$, in

Let's note that the relation $\left(\mathrm{t}_{\mathrm{in}}-\mathrm{t}_{\mathrm{h}}\right) \cdot \mathrm{z}_{\mathrm{h}}$ in the formula (2) means heating degree days (GSOP) [14]. For residential building, located on the territory of the Leningrad Region GSOP $=5221^{\circ} \mathrm{C}$ days. Thus, formula (2) will take a more shortened form:

$$
\mathrm{Q}=0.024 \cdot \mathrm{U} \cdot \mathrm{GSOP}
$$

Thus, we have defined the amount of heat losses $Q=50.1 \mathrm{~kW} \cdot \mathrm{h} / \mathrm{m}^{2}=43.1 \mathrm{Mcal} / \mathrm{m}^{2}$, which corresponds to a normal level of unit heat energy consumption on heating and ventilation systems of 2-3 storey connected buildings constructed after 2015 for a heating period, $q_{o, y e a r}=75 \mathrm{Mcal} / \mathrm{m}^{2}$.

Knowing useful floor area, we can calculate heat consumption of a building during a year: $\mathrm{Q}=50123.5 \mathrm{~kW} \cdot \mathrm{h}=43098.5 \mathrm{Mcal}$.

According to the II law of thermostatics, transmition of heat capacity in a pump is offset by the work of compressor (Michaelson scheme). For the work of heat pump having cooling source with the thermostat (with the constant temperature) is essential [16-24].

In rock soils (with the coefficient $\lambda=1 \ldots 3 \mathrm{~W} /(\mathrm{m} \cdot \mathrm{K})$ ) where the object of our research is located, the adiabatic conditions are executed and the thermal regulation of layers is held. In other words, for getting necessary heat output in this soil deep drilling is essential that will lead to high expenses.

Taking into account that in 20 meters zone from site development Glubokoe Lake is located, using pump taking heat from the outer water basin of an unlimited volume (such as lake) is more rational (Fig. 1). 


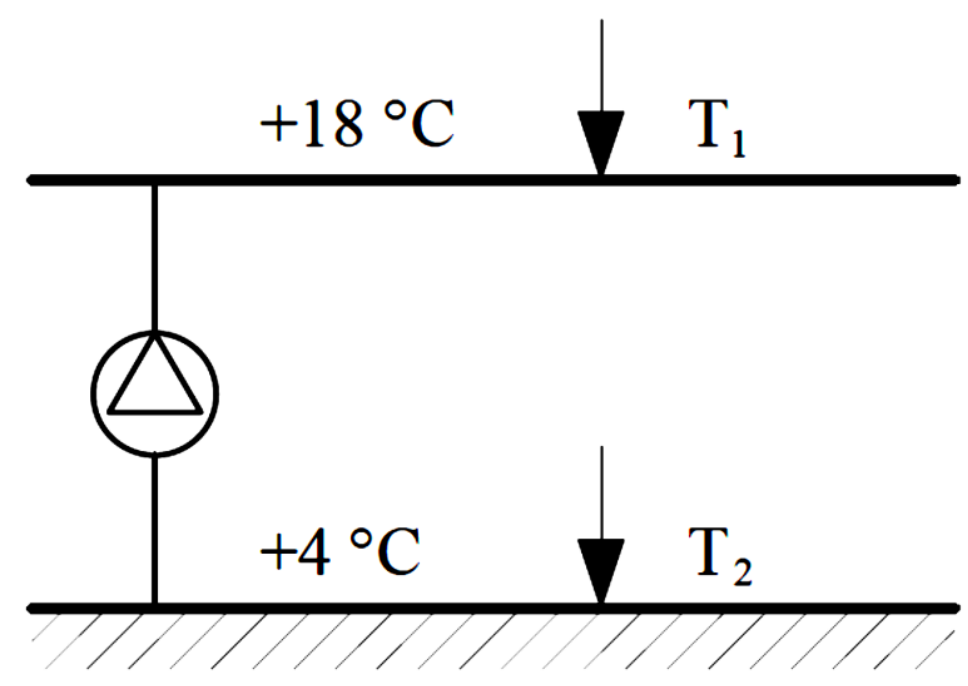

Figure 1. Temperature zones difference

$$
\varepsilon=\frac{\mathrm{q}_{2}}{1_{\mathrm{n}}} \longrightarrow \max
$$

The excess of cooling coefficient over 1 shows that by means of relatively high $\mathrm{q}_{2}$ and low $\ln$ we can get maximum increment of refrigeration efficiency.

It's known that 1 meter of a heat pump tube located on the bottom of a lake gives $50 \mathrm{~W}$ of heat energy. Let's calculate the parameters of a heat exchanger with account of 20 meters distance.

Heat transmission equation has the following form:

$$
\mathrm{Q}=\mathrm{k} \cdot \Delta \mathrm{t} \cdot \mathrm{A}_{\mathrm{TA}},
$$

where $\mathrm{k}$ - heat transmission coefficient;

$\Delta \mathrm{t}-$ temperature pressure;

$A_{T A}$ - surface area of a heat exchanger.

Calculations show that the surface of heat exchange, formed by tube sheet with the length of $5 \ldots 10 \mathrm{~m}$, filled with Freon gas (saturation temperature of which is minus $50^{\circ} \mathrm{C}$ ) might have the outer diameter equal to $8 \mathrm{~mm}$.

Out of economic considerations, there are two regimes of functioning: one is heat source in winter and another one is cold in summer. It is also used for water heating in DHW system [24-28]. So there is an economy in three directions: heat supply, pre-heating and air-cooling of ventilation air-conditioning systems, heating of water for DHW.

Methods of calculating capital costs for additional insulation, operating costs before and after thermal insulation, as well as the payback period of energy-saving measures are described in detail in the works [29-33]. To determine the simple payback, the following basic equation was obtained:

$$
\mathrm{T}=\frac{\Delta \mathrm{C}}{\Delta \mathrm{E}},
$$

where $\Delta C$ - capital expenditures, rub.;

$\Delta \mathrm{E}-$ economic effect achieved as a result of energy saving measures, rub./year:

$$
\Delta \mathrm{E}=\sum \mathrm{Q} \cdot \mathrm{c}_{\mathrm{T}},
$$

where $c_{T}$ - the rate for the calculation of the amount of payment for utility services with VAT in St. Petersburg for 2016 according to the data of the St. Petersburg Administration official website [34], rub./Gcal.

Capital costs for the heat pump installation (taking into account the energy consumed by the heat pump) amount to 4696380 rub.

Костенко В.А., Гафиятуллина Н.М., Семчук А.А., Куколев М.И. Геотермальный тепловой насос в концепции пассивного дома // Инженерно-строительный журнал. 2016. № 8(68). С. 18-25. 
The economic effect amount to 126663 rub. per year.

Heat tariffs increase annually. This means that the annual cost savings will increase with each subsequent year (heating period).

Taking into account the above-mentioned factors, the projected payback period of investment in additional facades insulation is determined by a logarithmic equation [19-24]:

$$
T=\frac{\ln \left[1+\frac{\Delta \mathrm{C}}{\Delta E} \cdot \frac{(r-i)}{(1+i)}\right]}{\ln \left[\frac{1+r}{1+i}\right]},
$$

where $r$ - coefficient characterizing the average annual growth of thermal energy tariffs;

$i$ - coefficient of future cash flows discounted at the key rate of the Central Bank of the Russian Federation.

Equation (8) allows to calculate the payback period (T) of energy-saving measures, taking into account the total capital expenditure for its implementation $(\Delta C)$, the rising cost of tariffs for thermal energy ( $r$ ), discounting future cash flows (i), achieved by cost-cutting as a result of the implementation of energy-saving measures.

It should be noted that several time-dependent parameters includes in the equation (8): the dynamics of tariff raising for thermal energy $(r)$ and interest rate (i), by which discounted future cash flows is estimated, accumulated as a result of the introduction of energy-saving measures. At the present time it is impossible to clearly know how these variable parameters will change over time in the future. Therefore, to solve the problem of estimating the projected payback period of investment in energy efficiency magnitude $r$ was adopted of the average over the last 5 years $-16 \%$, and the value $i-$ as of $2016-11 \%$.

In this case the payback period of investment will amount to 23 years.

\section{Results and Discussion}

The result of the research is the Passive House project. The following architectural, construction and engineering solutions aimed at energy savings were given:

- vertical distribution of internal rooms and reduction of the roof area. Compactness coefficient is 0.61 ;

- orientation of the glazed facade to the southwest, in accordance with the solar insolation;

- application of innovative thermal insulation material Cellulose Fibre as insulation of the building envelope;

- installation of the combined extract-and-input system with heat recovery;

- installation of the geothermal heat pump with two modes of operation: the source of cold in the winter and heat in the summer.

Energy-saving effect can be achieved only when all of these technical solutions are used together.

Numerous studies [1-11, 16-33] carried out in different countries of the world showed the prospect of development in the energy efficiency industry. Broad experience was gained in performing parametric evaluations and successfully developing appropriate passive solutions for different climates. The leading authority in the field is the Darmstadt Passivhaus Institut founded in 1996 as an independent research institution employing physicists, mathematicians and civil, mechanical and environmental engineers. Another important research center is at Fraunhofer Institute for Solar Energy in Freiburg.

\section{Conclusions}

In this paper, we give details about a project devoted to investigate in what extend renewable energy is useful for energy supply (i.e. heating, cooling and domestic hot water) in terms of technical feasibility and in terms of thermal comfort of passive houses.

A two-story 7-apartment townhouse was accepted for Passive House project. A simple ideal model is adopted for the subsoil heat exchanger. Based on the foregoing, it can be argued that the aim to determine the possibility of using geothermal heat pump in the Passive House has been achieved. Our results show that Pirmasens Passive House heating is necessary during November-March, with January requiring the highest level of heating. The yearly relative total thermal load is $10.2 \mathrm{kWh} / \mathrm{m}^{2}$, which is below the limit of $15 \mathrm{kWh} / \mathrm{m}^{2}$ allowed by passive house requirements. The conducted feasibility study showed that the payback period is less than 23 years old. 


\section{References}

1. Feist W., Schnieders J., Dorer V., Haas A. Re-inventing air heating: Convenient and comfortable within the frame of the Passive House concept. Energy and Buildings. 2005. No. 37. Pp. 1186-1203.

2. Badescu V. Simple and accurate model for the ground heat exchanger of a passive house. Renewable Energy. 2007. No. 32. Pp. 845-855.

3. Wang L., Gwilliam J. Case study of zero energy house design in UK. Energy and Buildings. 2009. No. 41. Pp. 1215-1222.

4. Karlsson J.F., Moshfegh B. Energy demand and indoor climate in a low energy building - changed control strategies and boundary conditions. Energy and Buildings. 2006. No. 38. Pp. 315-326.

5. Chlela F., Husaunndee A., Inard C., Riederer P. A new methodology for the design of low energy buildings. Energy and Buildings. 2009. No. 41. Pp. 982-990.

6. Parker D.S. Very low energy homes in the United States: perspectives on performance from measured data. Energy and Buildings. 2009. No. 5(41). Pp. 512-520.

7. Livchak V.I. Opredelenie normativov potreblenija kommunal'nyh uslug $v$ zhilyh domah [Definition of the utility services consumption norms in multiapartment buildings in large cities]. ABOK. 2012. No. 1. Pp. 64-70. (rus)

8. Passive Energy House Standard: Which requirements are necessary for the building and/or individual components. 2005.

9. Gorshkov A.S., Derunov D.V., Zavgorodniy V.V. Tehnologija i organizacija stroitel'stva zdanija $s$ nulevym potrebleniem jenergii [Technology and organization of the building with zero energy consumption]. Construction of Unique Buildings and Structures. 2013. No. 3. Pp. 12-23. (rus)

10. Gorshkov A.S., Gladkih A.A. Measures to improve energy efficiency in construction. Academia. Architecture and Construction. 2010. No. 3. Pp. 246-250.

11. Starkov V.N., Strelec K.I. Inzhenernoe oborudovanie zdanij $i$ sooruzhenij. Proektirovanie $i$ raschet sistem otoplenija [Engineering equipment of buildings and structures, Desighn and calculation of heating systems]. [Electronic resource]. System requirements: AdobeAcrobatReader. URL: http://elib.spbstu.ru/dl/2/3024.pdf (date of application: 14.11.2016). (rus)

12. Russian Set of Rules SP 131.13330.2012. Building climatology. The updated edition of Russian Building Norms and Rules SNiP 23-01-99. Moscow, 2013. (rus)

13. Russian State Standard GOST 30494-2011. Residential and public buildings. Microclimate parameters in the premises. Moscow, 2013. (rus)

14. Russian Set of Rules SP 50.13330.2012. Thermal protection of buildings. The updated edition of SNiP 23-022003. (rus)

15. TSN 23-340-2003. Jenergeticheskaja jeffektivnost' zhilyh i obshhestvennyh zdanij. Normativy po jenergopotrebleniju i teplozashhite [Russian Regional construction norms TSN 23-340-2003. Energy efficiency of residential and public buildings. Standards for energy consumption and thermal protection]. St. Petersburg, 2003. (rus)

16. Vasilyev G.P. Geotermal'nye teplonasosnye sistemy teplosnabzhenija i jeffektivnost' in primenenija $v$ klimaticheskih uslovijah Rossii [Geothermal heat pump heating systems and the effectiveness of their application in the Russian climatic conditions]. ABOK. 2007. No. 5. Pp. 58-66. (rus)

17. Badescu V. Economic aspects of using ground thermal energy for passive house heating. Renewable Energy.

\section{Литература}

1. Feist W., Schnieders J., Dorer V., Haas A. Re-inventing air heating: Convenient and comfortable within the frame of the Passive House concept // Energy and Buildings. 2005. № 37. Pp. 1186-1203.

2. Badescu V. Simple and accurate model for the ground heat exchanger of a passive house // Renewable Energy. 2007. № 32. Pp. 845-855.

3. Wang L., Gwilliam J. Case study of zero energy house design in UK // Energy and Buildings. 2009. № 41. Pp. 1215-1222.

4. Karlsson J.F., Moshfegh B. Energy demand and indoor climate in a low energy building - changed control strategies and boundary conditions // Energy and Buildings. 2006. № 38. Pp. 315-326.

5. Chlela F., Husaunndee A., Inard C., Riederer P. A new methodology for the design of low energy buildings // Energy and Buildings. 2009. № 41. Pp. 982-990.

6. Parker D.S. Very low energy homes in the United States: perspectives on performance from measured data // Energy and Buildings. 2009. № 5(41). Pp. 512-520.

7. Личвак В.И. Определение нормативов потребления коммунальных услуг в жилых домах // АВОК. 2012. № 1. C. 64-70.

8. Passive Energy House Standard: Which requirements are necessary for the building and/or individual components. 2005.

9. Горшков А.С., Дерунов Д.В., Завгородний В.В Технология и организация строительства здания с нулевым потреблением энергии // Строительство уникальных зданий и сооружений. 2013. № 3. С. 12-23.

10. Gorshkov A.S., Gladkih A.A. Measures to improve energy efficiency in construction // Academia. Architecture and Construction. 2010. № 3. Pp. 246-250.

11. Старков В.Н., Стрелец К.И. Инженерное оборудование зданий и сооружений. Проектирование и расчет систем отопления [Электронный ресурс]. Систем. требования: AdobeAcrobatReader. http://elib.spbstu.ru/dl/2/3024.pdf (дата обращения: 14.11.2016)

12. СП 131.13330.2012. Строительная климатология. Актуализированная редакция СНиП 23-01-99. М., 2013.

13. ГОСТ 30494-2011. Здания жилые и общественные Параметры микроклимата в помещениях. М., 2013.

14. СП 50.13330.2012. Тепловая защита зданий Актуализированная редакция СНиП 23-02-2003. М., 2013.

15. ТСH 23-340-2003. Энергетическая эффрективность жилых и общественных зданий. Нормативы по энергопотреблению и теплозащите. СПб, 2003.

16. Васильев Г.П. Геотермальные теплонасосные системы теплоснабжения и эфрфективность их применения в климатических условиях России // АВОК. 2007. № 5. C. 58-66.

17. Badescu V. Economic aspects of using ground thermal energy for passive house heating // Renewable Energy. 2007. № 32. Pp. 895-903.

18. Flaga-Maryanczyka A., Schnotalea J., Radonb J., Was K. Experimental measurements and CFD simulation of a ground source heat exchanger operating at a cold climate for a passive house ventilation system // Energy and Buildings. 2014. № 68. Pp. 562-570.

19. Lee K.S. Underground Thermal Energy Storage. Springer. London, 2013. Pp. 16.

20. Doherty P.S., Al-Huthaili S., Riffat S.B., Abodahab N Ground source heat pump - description and preliminary results of the Eco House system // Applied Thermal

Костенко В.А., Гафиятуллина Н.М., Семчук А.А., Куколев М.И. Геотермальный тепловой насос в концепции пассивного дома // Инженерно-строительный журнал. 2016. № 8(68). С. 18-25. 
2007. No. 32. Pp. 895-903.

18. Flaga-Maryanczyka A., Schnotalea J., Radonb J., Was K. Experimental measurements and CFD simulation of a ground source heat exchanger operating at a cold climate for a passive house ventilation system. Energy and Buildings. 2014. No. 68. Pp. 562-570.

19. Lee K.S. Underground Thermal Energy Storage. Springer. London, 2013. Pp. 16.

20. Doherty P.S., Al-Huthaili S., Riffat S.B., Abodahab N. Ground source heat pump - description and preliminary results of the Eco House system. Applied Thermal Engineering. 2004. No. 24. Pp. 2627-2641.

21. Florides G., Kalogirou S. Ground heat exchangers - a review of systems, models and applications. Renewable Energy. 2007. No. 32. Pp. 2461-2478.

22. Wu Y., Gan G., Verhoef A., Vidale P.L., Gonzalez R.G. Experimental measurement and numerical simulation of horizontal-coupled slinky ground source heat exchangers. Applied Thermal Engineering. 2010. No. 30. Pp. 25742583.

23. Nedviga P.N. Vozmozhnosti ispol'zovanija teplovyh akkumuljatorov i nizkopotencial'nogo tepla zemli pri otoplenii individual'nyh domov [The possibility of using thermal accumulators and low-grade heat of the earth for heating of individual houses]. Magazine of Civil Engineering. 2010. No. 3. Pp. 11-14. (rus)

24. Averyanova O.V. Jenergosberegajushhie tehnicheskie reshenija dlja mestno-central'nyh sistem obespechenija mikroklimata pri ispol'zovanii teplovyh nasosov v kachestve mestnyh agregatov, obedinennyh $v$ ediny] vodjanoj kontur [Energy saving solutions for microclimate support systems when using heat pumps as local units, combined into a single water circuit]. Magazine of Civil Engineering. 2011. No. 1. Pp. 37-45. (rus)

25. Bojic M. Optimization of heating and cooling of a building by employing refuse and renewable energy. Renew Energy. 2000. No. 20. Pp. 453-465.

26. Bühring A., da Silva P. Heat supply in passive houses with a compact ventilation device and integrated exhaust air heat pump. Proceedings of the 6th IEA Heat Pump Conference. 1999. No. 2. Pp. 1-8.

27. Kumar R., Sachdeva S., Kaushik S.C. Dynamic earthcontact building: a sustainable low-energy technology. Building and Environment. 2007. No. 42. Pp. 2450-2460.

28. Thiers S., Peuportier B. Thermal and environmental assessment of a passive building equipped with an earthto-air heat exchanger in France. Solar Energy. 2008. No. 82. Pp. 820-831.

29. Gorshkov A.S., Vatin N.I., Rymkevich P.P. Ekonomicheskaya effektivnost' investitsiy V energosberezhenie [Cost-effectiveness of investments in energy efficiency]. Inzhenernye sistemy. 2014. No. 3. Pp. 32-36. (rus)

30. Romanova A.A., Rymkevich P.P., Gorshkov A.S. Metodika rascheta prognoziruemykh srokov okupaemosti energosberegayushchikh meropriyatiy po utepleniyu zdaniy [Methods of calculating the projected payback period of energy-saving measures for buildings thermal insulation]. Technico-tehnologicheskie problemy servisa. 2014. No. 4. Pp. 68-74. (rus)

31. Kostenko V.A., Gafiyatullina N.M., Zulkarneev G., Gorshkov A.S. Solutions to improve the thermal protection of the administrative building. MATEC Web of Conferences. 2016. No. 73.

32. Averyanova O.V. Jekonomicheskaja jeffektivnost' jenergosberegajushhih meroprijatij [Cost-effectiveness of energy-saving measures]. Magazine of Civil Engineering. 2011. No. 5. Pp. 53-59. (rus)

33. Galvin R., Sunikka-Blank M. Including fuel price elasticity of demand in net present value and payback time

Kostenko V.A., Gafiyatullina N.M., Semchuk A.A., Kukolev M.I. Geothermal heat pump in the passive house concept. Magazine of Civil Engineering. 2016. No. 8. Pp. 18-25. doi: 10.5862/MCE.68.2
Engineering. 2004. № 24. Pp. 2627-2641.

21. Florides G., Kalogirou S. Ground heat exchangers - a review of systems, models and applications // Renewable Energy. 2007. № 32. Pp. 2461-2478.

22. Wu Y., Gan G., Verhoef A., Vidale P.L., Gonzalez R.G. Experimental measurement and numerical simulation of horizontal-coupled slinky ground source heat exchangers // Applied Thermal Engineering. 2010. № 30. Pp. 25742583.

23. Недвига П.Н. Возможности использования тепловых аккумуляторов и низкопотенциального тепла земли при строительный журнал. 2010. № 3. С. 11-14.

24. Аверьянова О.В. Энергосберегающие технические решения для местно-центральных систем обеспечения микроклимата при использовании тепловых насосов в качестве местных агрегатов, объединенных в единый водяной контур // Инженерно-строительный журнал. 2011. № 1. С. 37-45.

25. Bojic M. Optimization of heating and cooling of a building Energy. 2000. No. 20. Pp. 453-465.

26. Bühring A., da Silva $P$. Heat supply in passive houses with a compact ventilation device and integrated exhaust air heat pump // Proceedings of the 6th IEA Heat Pump Conference. 1999. No. 2. Pp. 1-8.

27. Kumar R., Sachdeva S., Kaushik S.C. Dynamic earthcontact building: a sustainable low-energy technology // Building and Environment. 2007. No. 42. Pp. 2450-2460.

28. Thiers S., Peuportier B. Thermal and environmental assessment of a passive building equipped with an earthto-air heat exchanger in France // Solar Energy. 2008. No. 82. Pp. 820-831.

29. Горшков А.С., Ватин Н.И., Рымкевич П.П. Экономическая эффективность инвестиций в энергосбережение. Инженерные системы. 2014. № 3. C. 32-36.

30. Романова А.А., Рымкевич П.П., Горшков А.С Метгодика расчета прогнозируемых сроков окупаемости энергосберегающих мероприятий по утеплению зданий // Технико-технологические проблемы сервисаю 2014. № 4. С. 68-74.

31. Kostenko V.A., Gafiyatullina N.M., Zulkarneev G., Gorshkov A.S. Solutions to improve the thermal protection of the administrative building // MATEC Web of Conferences. 2016. № 73.

32. Аверьянова О.В. Экономическая эфффективность энергосберегающих мероприятий // Инженерностроительный журнал. 2011. № 5. С. 53-59.

33. Galvin R., Sunikka-Blank M. Including fuel price elasticity of demand in net present value and payback time calculations of thermal retrofits: case study of German dwellings // Energy and Buildings. 2012. № 50. Pp. 219228.

34. Тарифы для расчета размера оплаты коммунальных услуг с НДС в Санкт-Петербурге на 2016 год [Электронный ресурc]. http://gov.spb.ru/helper/tarif/tarify-2016-goda/tarify-dlyarascheta-razmera-platy-za-kommunalnye-uslugi/ отоплении индивидуальных домов // Инженерноby employing refuse and renewable energy // Renew 
calculations of thermal retrofits: case study of German dwellings. Energy and Buildings. 2012. No. 50. Pp. 219228.

34. The rate for the calculation of the amount of payment for utility services with VAT in St. Petersburg [Electronic resource]. URL: http://gov.spb.ru/helper/tarif/tarify-2016goda/tarify-dlya-rascheta-razmera-platy-za-kommunalnyeuslugi/ (rus)

Valeriya Kostenko,

+7(999)2071735; kostenkolera@gmail.com

Nailya Gafiyatullina,

+7(911)1178891; gnelly12@mail.ru

Anna Semchuk, annesemchuk@gmail.com

Maxim Kukolev,

+79217540087; m_kukolev@mail.ru
Валерия Алексеевна Костенко $+7(999) 2071735$

эл. почта: kostenkolera@gmail.com

Наиля Мударисовна Гафриятуллина, +7(911)1178891; эл. почma: gnelly12@mail.ru

Анна Анатольевна Семчук, эл. почma: annesemchuk@gmail.com

Максим Игоревич Куколев,

+79217540087; эл. почma: m_kukolev@mail.ru

(C) Kostenko V.A., Gafiyatullina N.M., Semchuk A.A., Kukolev M.I., 2016

Костенко В.А., Гафиятуллина Н.М., Семчук А.А., Куколев М.И. Геотермальный тепловой насос в концепции пассивного дома // Инженерно-строительный журнал. 2016. № 8(68). С. 18-25. 